\title{
Phylogeographic Analysis of Mitochondrial DNA in the Nogays: A Strong Mixture of Maternal Lineages from Eastern and Western Eurasia
}

\author{
M. A. Bermisheva ${ }^{1}$, I. A. Kutuev' ${ }^{1}$ T. Yu. Korshunova ${ }^{1}$, \\ N. A. Dubova ${ }^{2}$, R. Villems ${ }^{3}$, and E. K. Khusnutdinova ${ }^{1}$ \\ ${ }^{1}$ Institute of Biochemistry and Genetics, Ufa Research Center, Russian Academy of Sciences, \\ Ufa, 450054 Russia \\ E-mail: marina_ber@omen.ru; ekkh@anrb.ru \\ ${ }^{2}$ Institute of Anthropology and Ethnology, Russian Academy of Sciences, \\ Moscow, 119334 Russia \\ ${ }^{3}$ Estonian Biological Center, Tartu University, \\ Tartu, 51010 Estonia \\ Received December 11, 2003
}

\begin{abstract}
Analysis of mtDNA markers in a population of the Nogays $(n=206)$, the people inhabiting the North Caucasus and speaking a Turkic language of the Altaic linguistic family, has revealed a high level of genetic diversity $(\mathrm{H}=0.99)$. The identified haplotypes include all major West Eurasian haplogroups, with the prevalence of $\mathrm{H}$ and $\mathrm{U}$ clusters (22 and $21 \%$, respectively), but the percentage of lineages specific for East Eurasian populations is the highest (40\%). Some other mtDNA variants in the Nogay population belong to the M1 haplogroups typical of northeastern Africa and U2 characteristic of Indian populations. Thus, components of different origin have contributed to the gene pool of Nogays.
\end{abstract}

Key words: mitochondrial DNA, haplotyping, ethnogenomics, Nogays

The ethnic and linguistic diversity of populations in the Caucasus, at the boundary of Europe and Western Asia, is high. The peoples of this region belong to four major linguistic groups (North-Caucasian, Kartvelian, Indo-European, and Altaic) and speak approximately 50 local languages. In addition, the Transcaucasian and North Caucasian populations have their original ethnic history. Hence, the Caucasus as a whole and its individual regions are important and interesting objects for studying the influence of linguistic diversity and geographic segregation on the genetic differentiation of peoples and the topology of their phylogenetic tree.

The genetic structure of the Nogays, the people speaking a Turkic branch of the Altaic linguistic family, is the least studied. They have descended from various Turkic and Mongolian tribes that belonged to the ulus (province) of the Golden Horde temnik (governor) Nogay, merged with the Turkic-speaking Polovtsy (Kipchaks), and adopted their language. The Nogay Horde diverged from the Golden Horde by the end of the 14th century. Numerous tribes of the Nogay Horde migrated over the regions located east and west of the Volga River, including the North Caucasian steppes where they now live [1].
The ethnic history of North Caucasian peoples is a product of complex migrational and cultural processes that took place not only in their native land, but also in the neighboring Kazakhstan, Middle Asia, Volga and Ural regions, Southern Siberia, and Transcaucasia. This fully applies to the Nogays. The medieval peoples who constituted their ethnic core belonged to various lineages and tribes. Interacting with each other, they formed new tribal associations and consolidated into a community of Eurasian people with a unique and diverse ethnic composition. Individual nationality groups-Kazakhs, Uzbeks, Kirghiz, Kara-Kalpaks, Bashkirs, Tatars, and others-have many common features in their history and composition [1].

The purpose of this work was to study the mitochondrial lineages of the Nogays and compare them with data on other peoples of the Caucasus and of Europe and Asia.

\section{EXPERIMENTAL}

The material (peripheral blood) was collected in 2001-2002 in the Nogaiskii raion of Dagestan (the villages Terekli-Mekteb, Karagas, Kuntabar, and Chervlennye Buruny) and Adyge-Khabal'skii raion of the Karachai-Cherkess Republic (the villages Erken- 
Khalk, Erken-Shakhar, Adil'-Khalk, and Ikon-Khalk). Blood samples were taken after a medical examination from adults, who were informed about the purposes of population genetic studies. Ethnic affiliation was determined by questioning, taking into account the nationality through three generations.

DNA was isolated from the peripheral blood by conventional phenol-chloroform extraction. The hypervariable segment I (HVSI) of the mtDNA reference region was amplified using primers A15909 and B16498, which was followed by the sequencing of a fragment between positions 16,024 and 16,400 bp. Primers H15975 and F16420 from the DYEnamicTM ET terminator cycle sequencing premix kit (Amersham) were used. DNA haplogroups were determined using RFLP analysis with restriction endonucleases shown in Table 1. MtDNA mutations were numbered according to the Cambridge reference sequence (CRS) [2]. The parsimony and reduced median network methods were used to accurately determine the phylogenetic relationships between haplotypes within the entire Nogay sample [3].

\section{RESULTS AND DISCUSSION}

At the end of the 20th century, the main specific types of mtDNA were described and its mutations were determined, which made it possible to classify human haplogroups [4-6]. The nomenclature of Eurasian mtDNA lineages is based on the combined data on polymorphism of both reference and coding mtDNA regions (Fig. 1) [7-9]. The diversity of mtDNA haplogroups in the ethnic group of Nogays $(n=206)$ has been characterized in this study. The phylogenetic tree of mtDNA lineages of the Nogay population is based on the HVSI polymorphism of the mtDNA reference region and on RFLP analysis of the coding mtDNA region (Fig. 2). Table 2 shows the frequencies of haplogroups in the Nogay population and some other populations of the world, including the Caucasus.

Both West and East Eurasian haplogroups of the Nogays population are highly diverse, which is an important feature of the Nogay gene pool. No founder effect is observed (except for haplogroup U3), indicating that numerous populations carrying different sets of both West and East Eurasian mtDNA variants have been involved in the formation of the Nogay population.

In Nogays, the frequencies of $\mathrm{H}$ and $\mathrm{U}$ clusters are the highest (22 and $21 \%$, respectively). The frequency of haplogroup $\mathrm{H}$ is known to be high in West and North Europe (40-50\%); medium frequency (20$40 \%$ ) in the southern and southwestern parts of the continent, North Africa, East Europe, and Turkey; and low (less than 20\%) in the Near East, India, and Central Siberia. Haplogroup $\mathrm{H}$ is assumed to have originated in the Near East 25,000-30,000 years ago [6]. In
Table 1. Restriction sites in the coding mtDNA region and haplogroup-determining restriction endonucleases

\begin{tabular}{|c|c|}
\hline $\begin{array}{l}\text { Restriction site and restriction } \\
\text { endonuclease }\end{array}$ & Haplogroup \\
\hline $73(73 \mathrm{GA})-A l w 44 \mathrm{I}$ & $\mathrm{HV}$ \\
\hline $663(663 \mathrm{AG})-\mathrm{Hae}$ III & A \\
\hline 1715 (1719GA) - DdeI & N1x \\
\hline 4577 (4580GA) - NlaIII & $\mathrm{V}$ \\
\hline 4643 (4646TC) - RsaI & $\mathrm{U} 4$ \\
\hline $4830(4833 \mathrm{AG})-$ HaeII & $\mathrm{G}$ \\
\hline $5176(5178 \mathrm{CA})-A l u \mathrm{I}$ & $\mathrm{D}$ \\
\hline 5416 (5417GA) - TasI & N9 \\
\hline $7025(7028 \mathrm{CT})-A l u \mathrm{I}$ & $\mathrm{H}$ \\
\hline 7598 (7600GA) - HhaI & $\mathrm{E}$ \\
\hline $8249(8251 \mathrm{CT})+A v a \mathrm{II}$ & N1b \\
\hline 8994 (8994GA) - HaeIII & $\mathrm{W}$ \\
\hline 9052 (9055GA) - HaeII & $\mathrm{K}$ \\
\hline $10032(10034 \mathrm{TC})+A l u \mathrm{I}$ & I \\
\hline $10394(10398 \mathrm{AG})+D d e \mathrm{I}$ & N1a \\
\hline $10397(10400 \mathrm{CT})+A l u \mathrm{I}$ & M \\
\hline $12308(12308 \mathrm{AG})+H i n f \mathrm{I}$ & $\mathrm{U}$ \\
\hline 12406 (12406GA) - HincII & $\mathrm{F} 1$ \\
\hline $12498(12501 \mathrm{GA})-$ NlaIII & N1 \\
\hline $12704(12705 \mathrm{CT})-\mathrm{MboII}$ & $\mathrm{R}+\mathrm{N}$ \\
\hline $13262(13263 \mathrm{AG})+A l u \mathrm{I}$ & $\mathrm{C}$ \\
\hline $13366(13368 \mathrm{GA})+$ BamHI & $\mathrm{T}$ \\
\hline 13704 (13708GA) - BstOI & $\mathrm{J}$ \\
\hline $14068(14070 \mathrm{AG})+\operatorname{Taq} \mathrm{I}$ & U1 \\
\hline 14465 (14470TC) +AceI & $\mathrm{X}$ \\
\hline $14766(14766 \mathrm{TC})+\mathrm{Mse} \mathrm{I}$ & $\mathrm{HV}$ \\
\hline $15904(15904 \mathrm{CT})+$ MseI & pre-V \\
\hline $8281-9$ bp del & $\mathrm{B}$ \\
\hline
\end{tabular}

Note: Transitions and transversions leading to either the formation or loss of the corresponding restriction site are indicated in parentheses.

Nogays, haplogroup $\mathrm{H}$ occurs with a medium frequency and has a relatively high diversity of lineages, some of which have been found in other Caucasian populations. This cluster reflects a well-defined "starshaped" phylogeny. A comparison of the frequency of this haplogroup in the Nogays and other Caucasian populations has shown that it is somewhat lower in Georgians and southern Ossetians but higher in Armenians and Adygeis (Table 2) [10]. MtDNA variation has also been studied in some Caucasian populations [11], but the topology of mitochondrial lineages is not presented in this work, and we cannot compare it with our results. In general, cluster $\mathrm{H}$ dominates in all populations of the Caucasus and Europe. A subcluster of 


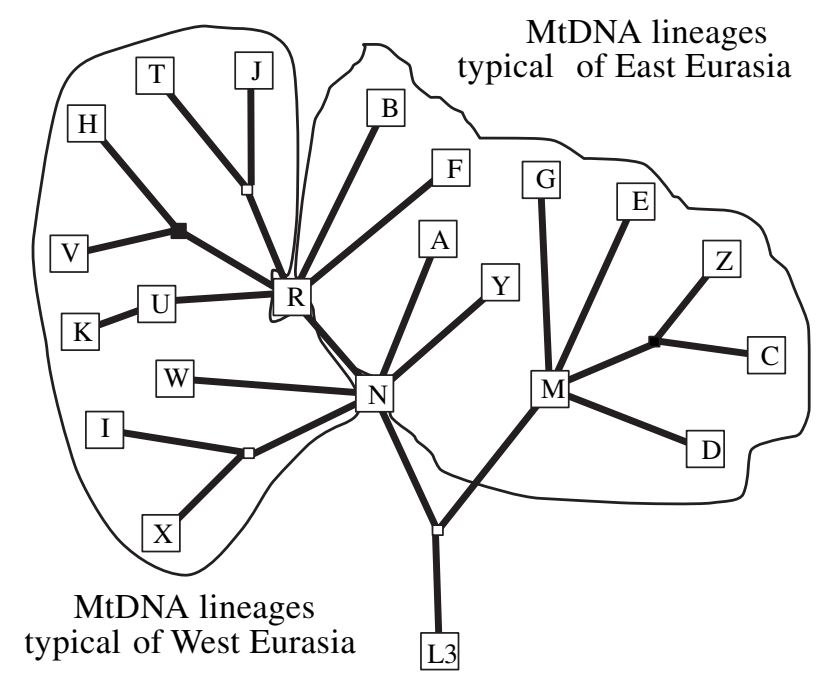

Fig. 1. Phylogenetic tree of the major mitochondrial DNA haplogroups in Eurasian populations.

haplogroup $\mathrm{H}$ with transitions at positions 16,293 and 16,311 was identified in the Nogays as well as in Europeans, whereas other peoples of the Caucasus and East Mediterranean area, including Turks, lack this subcluster $[10,12,13]$. These markers are rare in Europe (except for Estonia) [10, 14, 15]. Expansion of this sublineage began approximately $5200 \pm 1700$ years ago, i.e., in the Late Neolithic. On the other hand, the mtDNA lineages of $\mathrm{H} 8$ subgroup with substitutions at positions 16,288 and 13100 in the Nogays is evidence for the influence of Near East populations on the formation of their gene pool.

The phylogeography of haplogroup $\mathrm{V}$ and its pre$\mathrm{V}$ "precursor" was recently described in detail by Torroni et al. [16]. This haplogroup is widespread throughout Europe, including its eastern part (with a medium frequency), so that its occurrence in the Nogays is quite natural. At the same time, the Adygeis and the populations of Central Asia speaking Turkic languages lack this haplogroup.

Cluster $\mathrm{U}$ has been identified in Europeans, Indians, and populations of sub-Sahara $[8,17,18]$. As determined from the minimum time of divergence, this group is ancient $[9,14]$ and included several haplogroups (U1-U8) that make up about $7 \%$ in the European populations. The frequency of cluster $U$ is approximately equal in the Nogays, Ossetians, Armenians, and Adygeis. In the Nogays, however, the level of diversity of U subclusters is higher, and they differ from $U$ subclusters of other Caucasian populations (Table 2) [9, 10].

The absolute frequency of haplogroup U3 is high $(5.3 \%)$ in both the entire sample of Nogays and in cluster U proper (30\%), although this haplogroup has a low level of diversity with one dominant haplotype.
At the same time, U3 is extremely rare in the populations inhabiting the Volga-Ural region [19] and Central Asia [12], as well as in Russians [20, 21] and peoples of the Caucasus [10]. However, a phylogeographic analysis of these lineages clearly shows that the substitution at position 16,168 is often observed in populations of the Caucasus and Near East, whereas transition 16,390 occurs in the Near East and Georgia [10].

The U5 haplogroup prevails in the Saami (53.8\%) and is frequent in other European populations $[15,22]$. The frequency of this haplogroup in the Nogays $(2.9 \%)$ is similar to that in the Armenians, Ossetians, and Georgians [10]. The haplotype with substitutions at positions 16,144, 16,189, and 16,270, which is encountered in the Saami, Finns, and Karels with respective frequencies of $37.4 \%, 2 \%$, and $6 \%$ $[15,22]$, has been identified in the Nogays only once.

As shown previously, the highest frequency of haplogroup U4 is characteristic of trans-Ural Bashkirs and Chuvash inhabiting the Volga-Ural region [19] and of Georgians in the Caucasus [10]. Among the Nogays, the frequency of haplogroup U4 is low (1.9\%). This haplogroup has not been identified in Iran among Kurds and Ossetians, i.e., among Indo-Iranian peoples.

The frequency of haplogroup U1 in the Nogays is higher than in Europe, India, and Ethiopia and similar to that in the Turks and Altais [18].

The Iranian-speaking and more ancient pre-Iranian-speaking groups, to which the Ossetians are most closely related anthropologically, were the basic component of all nomadic populations of Eurasian steppes. With respect to the Nogays, the role of IndoIranian tribes in their formation is still debated. In our sample, we have found haplogroup U7 with a typical transversion at position 16,318. The frequency of this haplogroup in East Europe [19] and Central Asia [12] is as low as $0.3 \%$, whereas it has a high frequency in Iran and India [18], which confirms the role of the Indo-Iranian component in Nogay ethnogeny.

Thus, we have found that the diversity within the $U$ cluster in the Nogays is higher than in Europeans.

Haplogroups $\mathrm{T}$ and J, which have a common substitution at position 16,126, stem from the Near East. They diverged approximately 25,000 and 42,000 years ago, respectively [14]. Their respective frequencies in the Nogays are $4.4 \%$ and $2.9 \%$. One sublineage of haplogroup $\mathrm{J}(16,063)$ is related to the Bulgarians, and another one $(16,187)$, to the Armenians and Georgians.

During the mid-16th century, most tribes of the Nogay Horde became vassals of the Moscow principality, which led to close relations between the Nogays and Slavs in the following period. This might explain the fact that the entire set of mtDNA lineages characteristic of the European populations occurs in the Nogays with a frequency exceeding $50 \%$. On the other hand, the prevalence of West Eurasian mtDNA 


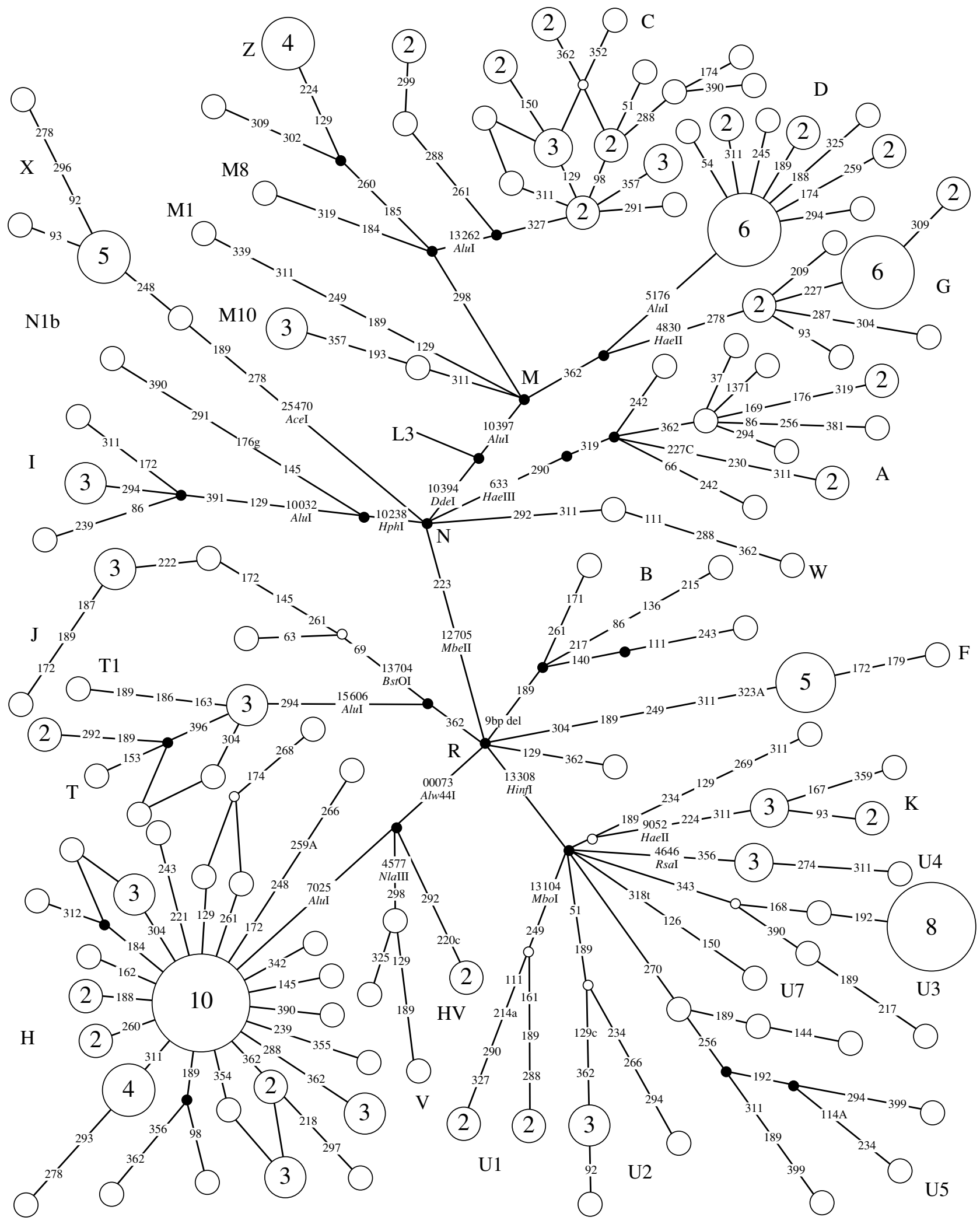

Fig. 2. Phylogenetic tree of mtDNA lineages in the Nogay population. The size of each circle is proportional to the haplotype frequency. Mutations are determined with regard to the Cambridge reference sequence of the hypervariable segment I; only the last three digits of five-digit numbers are shown (i.e., 223 instead of 16,223). The restriction sites of the coding mtDNA region are indicated in each cluster. Letters designate mtDNA haplogroups. 
Table 2. Frequencies of mtDNA haplogroups (\%) in some populations of the Caucasus and other regions of the world

\begin{tabular}{|c|c|c|c|c|c|c|c|c|c|}
\hline $\begin{array}{l}\text { Haplo- } \\
\text { group }\end{array}$ & $\begin{array}{c}\text { Adygeis } \\
(50)[5]\end{array}$ & $\begin{array}{c}\text { Nogays } \\
(206)\end{array}$ & $\begin{array}{c}\text { Kazakhs } \\
(82)[12,26]\end{array}$ & $\begin{array}{l}\text { Kirghiz } \\
\text { (92) [12] }\end{array}$ & $\begin{array}{c}\text { Uigurs (99) } \\
{[12,26]}\end{array}$ & $\begin{array}{l}\text { Mongols } \\
(103)[25]\end{array}$ & $\begin{array}{l}\text { Bashkirs } \\
\text { (221) [19] }\end{array}$ & $\begin{array}{c}\text { Turks } \\
\text { (218) [9] }\end{array}$ & $\begin{array}{c}\text { Azerbaijanis } \\
\text { (48) [9] }\end{array}$ \\
\hline $\mathrm{L}$ & & & 1.22 & 1.09 & 2.02 & & & 2.78 & \\
\hline M1 & & 0.48 & & 1.09 & & & & & \\
\hline A & & 5.34 & 7.32 & 3.26 & 6.06 & 3.88 & 3.60 & 0.46 & \\
\hline B & & 1.46 & 3.66 & 6.52 & 4.04 & 9.71 & 0.90 & 0.46 & \\
\hline $\mathrm{C}$ & 6.00 & 12.14 & 10.98 & 14.13 & 4.04 & 14.56 & 11.80 & 1.39 & 4.17 \\
\hline $\mathrm{Z}$ & & 2.43 & 8.54 & 1.09 & & 3.88 & 0.90 & & \\
\hline $\mathrm{D}$ & & 7.77 & 17.07 & 19.57 & 15.15 & 30.10 & 9.00 & 1.85 & \\
\hline $\mathrm{F}$ & & 2.91 & 3.66 & 3.26 & 7.07 & 5.83 & 6.32 & 0.46 & 2.08 \\
\hline G & & 6.31 & 3.66 & 8.69 & 5.05 & 2.91 & 4.50 & & \\
\hline $\mathbf{M}^{*}$ & & & & 3.26 & & 2.91 & 1.40 & & \\
\hline M10 & & 1.94 & 1.22 & & & 3.88 & & & \\
\hline M7 & & & 1.22 & & 5.05 & 2.91 & 0.48 & & \\
\hline M8 & & 0.48 & & & 3.03 & 0.97 & & & \\
\hline M9 & & & 2.44 & 2.17 & 2.02 & 0.97 & & & \\
\hline Y & & & 1.22 & & & 1.94 & 0.48 & 0.46 & \\
\hline N9 & & & & 3.26 & 1.01 & 1.94 & 1.44 & & \\
\hline $\mathrm{N} 1 \mathrm{a}$ & & & & & & & 3.60 & 0.46 & \\
\hline N1b & & 0.48 & & & & & & 0.93 & \\
\hline $\mathrm{R}$ & 10.00 & 0.48 & & & 2.02 & & & 1.85 & 2.08 \\
\hline pre-V & & 1.46 & & & & & 0.48 & & \\
\hline $\mathrm{V}$ & & 0.48 & & & & & 2.87 & 0.93 & 4.17 \\
\hline $\mathrm{H}$ & 28.00 & 22.33 & 14.63 & 16.30 & 16.16 & 7.77 & 12.20 & 28.70 & 29.17 \\
\hline $\mathrm{HV}$ & & 0.97 & 4.83 & 1.09 & & & 0.48 & 4.63 & 2.08 \\
\hline pre-HV & & & & 1.09 & 2.02 & & & 1.39 & 2.08 \\
\hline I & & 2.43 & & 2.17 & & & 1.44 & 2.31 & 2.08 \\
\hline $\mathrm{J}$ & 4.00 & 2.91 & 1.22 & 5.43 & 2.02 & & 3.20 & 10.19 & 4.17 \\
\hline $\mathrm{T}$ & 14.00 & 4.37 & 8.54 & 3.26 & 2.02 & 0.97 & 5.40 & 12.04 & 16.67 \\
\hline U1 & 6.00 & 1.94 & & 2.17 & 1.01 & 0.97 & & 4.63 & \\
\hline $\mathrm{U} 2$ & 2.00 & 2.42 & 1.22 & & 5.05 & 2.91 & 0.50 & 1.39 & \\
\hline U3 & 14.00 & 5.34 & & & & & & 7.41 & 2.08 \\
\hline U4 & 4.00 & 1.94 & 1.22 & & 5.05 & & 12.70 & 1.85 & 8.33 \\
\hline U5 & 8.00 & 2.91 & 2.44 & 1.09 & & & 13.60 & 0.93 & 8.33 \\
\hline U7 & & 2.91 & & & 4.04 & & & 0.93 & \\
\hline $\mathrm{K}$ & 2.00 & 2.91 & & & 2.02 & 0.97 & 1.44 & 5.56 & 2.08 \\
\hline U8 & & 0.48 & & & & & 0.48 & 0.46 & \\
\hline $\mathrm{U}^{*}$ & & & & & & & & 0.46 & \\
\hline $\mathrm{W}$ & 2.00 & 0.97 & 2.44 & & 3.03 & & 0.48 & 2.31 & 4.17 \\
\hline X & & 3.88 & & & 1.01 & & & 2.78 & 4.17 \\
\hline $\begin{array}{l}\text { Uniden- } \\
\text { tified }\end{array}$ & & & 1.22 & & & & & & 2.08 \\
\hline
\end{tabular}

Note: Figures in parenthesis and square brackets show the number of examined individuals and reference, respectively. Asterisks indicate haplotypes that belong to none of the subgroups of the given haplogroup. "Unidentified" refers to mtDNA types that have not been identified by RFLP analysis and sequencing. 
lineages in the Nogay gene pool might stem from the time when the Turkic-speaking Pechenegs and Polovtsi invaded the North Caucasus: these people, as well as the Khazars who already lived in this region, had probably assimilated some Indo-Iranian-speaking nomadic populations of the steppe zone.

The East Eurasian lineages typical of the indigenous populations of Siberia, Mongolia, and China occur among the Nogays with a fairly high frequency (about 40\%) [23-27]. In East Eurasia, the mtDNA lineages fall into two clusters, $\mathrm{M}$ or $\mathrm{N}$, which originate from the African cluster L3 [7]. In Asia, approximately 55\% of East Asian and Siberian mtDNA markers contribute to the $M$ superhaplogroup, which includes the related clusters C, Z, G, D, E, and others. The remaining East Eurasian mtDNA lineages contribute to the A, B, F, Y, and N9 haplogroups. The frequency of the $\mathrm{M}$ haplogroup and its subhaplogroups is extremely low in Europe (about $1.65 \%$ ). It has been shown previously that at most $6 \%$ of Saami and about $2 \%$ of Finn mtDNAs are members of the Asian $\mathrm{M}$ superhaplogroup, which indicates that the Mongoloid component prevails in West Europe [15, 22]. A recent analysis of the Volga-Ural populations has shown that in some of them, for example in the Turkic-speaking Bashkirs and Udmurts belonging to the Finno-Ugric language family, the frequency of East Eurasian lineages is as high as 42 and $21 \%$, respectively [19]. Macrocluster $\mathrm{N}$ is common to European and Asian populations.

In the Nogays, the frequency of haplogroup M (29\%) is much higher than in other peoples studied in the Caucasus [10]. It should be emphasized that our sample proved to include only one variant of the M1 haplogroup with transitions at positions 16,189, 16,223, 16,249, and 16,311 , which is specific for the inhabitants of northeastern Africa. This motif is rare in the Mediterranean and Near East [13] and has been identified in single cases among the Ossetians, Georgians, and Kirghiz [10, 12]. At the same time, the variants of haplogroup U6 contributing to the $U$ cluster typical of Eurasians have not been found in the Nogays. These data can provide a deeper insight into the pathways of ancient migration to eastern and northeastern Africa and the place of M1 haplogroup origin.

Among the peoples studied in the Caucasus, the M8 and M10 lineages were found only in the Nogays. The high frequency of the $\mathrm{C}, \mathrm{G}$, and $\mathrm{D}$ subhaplogroups and a lower frequency of the F, B, A, and $\mathrm{Z}$ haplogroups are also characteristic of the Nogays. Note that both the frequency of East Eurasian haplogroups and individual mtDNA lineages are similar in the Nogays, Kazakhs, and Bashkirs [12, 19, 26].

The maximum frequency of haplogroup $\mathrm{C}$, a branch of cluster $\mathrm{M}$, is characteristic of the Evenki and Yukagir $(50 \%)$ [28]. This haplogroup is frequent in populations of North Siberia (30\%) and less frequent
(10\%) in the Chukchi, Eskimos, and Itelmen in the east; Kazakh and Mongols in the south, and Selkup and Ket in the west [24, 27]. In the Turkic-speaking populations of the Volga-Ural region, the frequency of this haplogroup decreases from $11.8 \%$ in the Bashkir to $1.8 \%$ in the Tatar and Chuvash [19]. In the Caucasus, haplogroup $\mathrm{C}$ is most widespread among the Nogays, and its frequency is similar to that among the Bashkir (Table 2), which confirms once again that these two peoples are closely related [29].

The $\mathrm{C}$ haplogroup has a "sister" group $\mathrm{Z}$, which occurs with the highest frequency in the Evenki, Kazakh, and Chinese (26, 8, and 8\%, respectively). The Evenki, Ket, Selkup, Buryat, Tuvin, and populations of the North Caucasus lack haplogroup Z, whereas some Finno-Ugric populations, the Udmurt and Saami, do have this haplogroup [12, 15, 19, 22]. In the Nogays, we have identified haplogroup $\mathrm{Z}$ in $2.4 \%$ of cases. Among Turkic-speaking populations, a low frequency of this haplogroup has been determined in the Bashkirs, Tatars, and Kirghiz [19].

In the Nogays, the frequency of haplogroup D $(7.8 \%)$ is the second highest among East-Eurasian haplogroups. This haplogroup is common in the Mongols and Siberian populations (30,1 and 13\%, respectively) but rare in the populations of Southeastern Asia. In the Caucasus, this haplogroup has been revealed only in North Ossetia and Georgia, where its frequency is low [10].

Note that we have identified the F haplogroup in the studied sample of Nogays. This haplogroup is typical of Southeastern Asia, Altai, Kazakhstan, and Mongolia, but not of East Europe except for Hvar Island in Croatia [30] and Bashkir populations of the Volga-Ural region [19]. However, the high frequency of the $\mathrm{F}$ haplogroup in the last two cases can be explained by the founder effect under conditions of isolation.

The presence of the A haplogroup outside Northern and Eastern Asia and America has not been reported so far [4]. The frequency of this haplogroup in the studied sample of Nogays was $5.3 \%$. In addition, the frequency of haplogroup B was $1.5 \%$ in this population. Haplogroup B has previously been identified in southern Siberia among the Buryat, Tuvin, and Altai [23] and, with a high frequency, in Mongolia [25]. These populations are regarded as ancestral to the B haplogroup-carrying populations of native Americans. This haplogroup occurs with a fixed frequency in the populations of Polynesia and New Zealand. Among peoples of the Caucasus, it has been identified in only one Armenian out of 192 examined individuals [10].

The first stage in the evolution of the Nogay population was connected with the ancient Turkic tribes (the 6th-8th centuries). In the Middle Ages, the tribes of the Pecheneg union (the 9th-11th centuries), the 
Kipchak union (the 11th-13th centuries), the Golden Horde (the 13th-15th centuries), and the Nogay Horde (the 11th-17th centuries) contributed to this process [1]. Apparently, this is why the mtDNA haplotypes typical of Central Asia, Siberia, and Mongolia have been identified in this study. The presence of U7 lineages in the Nogays confirms the fact that, along with Turkic-speaking tribes, the Nogay Horde included Indo-Iranian populations presumably related to the Usuni-Uisuni. The descendants of ancient Uisuni who inhabited the Seven-River Land between the 3rd century B.C. and 5th century A.D. are currently encountered among the Nogays. Nogay ethnogeny involved interrelations with not only the Turkic world, but also with other neighbors inhabiting the steppes of southern Russia, the Volga region, the Crimea, and the North Caucasus, which is reflected in the gene pools of many people [1]. In particular, this fact may account for the diversity of West Eurasian mtDNA lineages characteristic of the Nogays.

Thus, the level of diversity of mtDNA haplotypes and the corresponding haplogroups in the sample of Nogays is very high. According to the results of clustering, most mtDNA types in the Nogays belong to haplogroups characteristic of West Eurasian populations. The high frequencies of the $\mathrm{C}, \mathrm{G}, \mathrm{D}, \mathrm{A}, \mathrm{B}$, and $\mathrm{F}$ haplogroups indicate the involvement of Siberian and Central Asian components into Nogay ethnogeny. Among all peoples studied in the North Caucasus, the Nogays have the highest frequency of East Eurasian lineage markers. In addition, they carry mtDNA lineages similar to those of Indian populations. An explanation of this fact can be found in the ethnic history of Nogays. They belong to the Turkic world and cannot be considered apart from their neighbors, with whom the Nogays have been in direct contact for many centuries.

\section{ACKNOWLEDGMENTS}

This work was supported by the Russian Foundation for Basic Research (01-04-48487) and the Ministry of Science and Education (43.073.1.1.2508). The expedition was organized by the Miklukho-Maklai Institute of Ethnology and Anthropology, Russian Academy of Sciences, and supported by the State Project "Nasledie" (Stavropol).

\section{REFERENCES}

1. Kereitov R.Kh. 1999. Etnicheskaya istoriya nogaitsev (Ethnic History of the Nogays). Stavropol.

2. Anderson S., Bankier A., Barrell B., et al. 1981. Sequence and organization of the human mitochondrial genome. Nature. 290, 457-465.

3. Bandelt H.-J., Forster P., Sykes B., et al. 1995. Mitochondrial portraits of human populations using median networks. Genetics. 141, 743-753.
4. Wallace D., Brown M., Lott M. 1999. Mitochondrial DNA variation in human evolution and disease. Gene. 238, 211-230.

5. Macaulay V., Richards M., Hickey E., et al. 1999. The emerging tree of West Eurasian mtDNA: A synthesis of control-region sequences and RFLPs. Am. J. Hum. Genet. 58, 1309-1322.

6. Richards M., Macaulay V., Bandelt H.-J., et al. 1998. Fhylogeography of mitochondrial DNA in western Europe. Ann. Hum. Genet. 62, 241-260.

7. Kivisild T., Tolk H.-V., Paric J., et al. 2002. The emerging limbs and twigs of the East Asian mtDNA tree. Mol. Biol. Evol. 19, 1737-1751.

8. Torroni A., Huoponen K., Francalacci P., et al. 1996. Classification of European mtDNA from an analysis of three European populations. Genetics. 144, 1835-1850.

9. Richards M., Macaulay V., Hickey E., et al. 2000. Tracing European founder lineages in the Near Eastern mtDNA pool. Am. J. Hum. Genet. 67, 1251-1276.

10. Tambets K., Kivisild T., Metspalu E., et al. 2000. The topology of the maternal lineages of the Anatolian and Trans-Caucasus populations and the peopling of Europe: Some preliminary considerations. In: Archaeogenetics: DNA and Population Prehistory of Europe. Eds. Renfrew C., Boyle K. Cambridge: McDonald Institute for Archaeological Research, 2000, pp. 219-235.

11. Nasidze I., Stoneking M. 2001. Mitochondrial DNA variation and language replacements in the Caucasus. Proc. R. Soc. Lond. 268, 1197-1206.

12. Comas D., Carafell F., Mateu E., et al. 1998. Trading genes along the Silk Road: Mitochondrial DNA sequences and the origin of Central Asian populations. Am. J. Hum. Genet. 63, 1824-1838.

13. Corte-Real H., Macaulay V., et al. 1996. Genetic diversity in the Iberian Peninsula determined from mitochondrial sequence analysis. Ann. Hum. Genet. 60, 331-350.

14. Richards M., Corte-Real H., et al. 1996. Paleolithic and Neolithic lineages in the European mitochondrial gene pool. Am. J. Hum. Genet. 59, 185-203.

15. Lahermo P., Sajantila A., Sistonen P., et al. 1996. The genetic relationship between the Finns and the Finnish Saami (Lapps): Analysis of nuclear DNA and mtDNA. Am. J. Hum. Genet. 58, 1309-1322.

16. Torroni A., Bandelt H.-J., Macaulay V., et al. 2001. A signal, from human mtDNA, of postglacial re-colonization in Europe. Am. J. Hum. Genet. 69, 844-852.

17. Kivisild T., Papiha S., Rootsi S. 2000. An Indian ancestry: A key for understanding human diversity in Europe and beyond. In: Archaeogenetics: DNA and population prehistory of Europe. Eds. Renfrew C., Boyle K. Cambridge: McDonald Institute for Archaeological Research, 2000. pp. 267-275.

18. Kivisild T., Bamshad M., Kaldma K., et al. 1999. Deep common ancestry of Indian and Western Eurasian mitochondrial DNA lineages. Curr. Biol. 9, 1331-1334.

19. Bermisheva M, Tambets K, Villems R., et al. 2002. Diversity of mtDNA lineages in populations of the Volga-Ural region. Mol. Biol. 6, 990-1001.

20. Malyarchuk B., Grzybowski T., Derenko M., et al. 2002. Mitochondrial DNA variability in Poles and Russians. Ann. Hum. Genet. 66, 261-283.

MOLECULAR BIOLOGY Vol. $38 \quad$ No. 42004 
21. Malyarchuk B., Derenko M. 2001. Mitochondrial DNA variability in Russians and Ukrainians: Implication to the origin of the Eastern Slavs. Ann. Hum. Genet. 65, 63-68.

22. Sajantila A., Salem A.-H., et al. 1996. Paternal and maternal DNA lineages reveal a bottleneck in the founding of the Finnish population. Popul. Biol. 93, 12035-12039.

23. Derenko M., Malyarchuk B., Dambueva I., et al. 2000. Mitochondrial DNA variation in two South Siberian aboriginal populations: Implication for the genetic history of North Asia. Hum. Biol. 72, 945-973.

24. Schurr T., Sukernik R., Starikovskaya Y., et al. 1999. Mitochondrial DNA variation in Koryaks and Itelmen: Population replacement in the Okhotsk Sea-Bering Sea region during the Neolithic. Am. J. Phys. Anthropol. 108, 1-39.

25. Kolman C., Sambuughin N., Bermingham E. 1996. Mitochondrial DNA analysis of Mongolian populations and implications for the origin of New World founders. Genetics. 142, 1321-1334.
26. Yao Y.-G., Lu X.-M., Luo H.-R., et al. 2000. Gene admixture in the Silk Road region of China: Evidence from mtDNA and melanocortin I receptor polymorphism. Genes Genet. Syst. 75, 173-178.

27. Starikovskaya Y., Sukernik R., Schurr T., et al. 1998. MtDNA diversity in Chukchi and Siberian Eskimos: Implications for the Genetic History of Ancient Beringia and the peopling of the New World. Am. J. Hum. Genet. 63, 1473-1491.

28. Torroni A., Sukernik R.I., Schurr T.G., et al. 1993. MtDNA variation of aboriginal Siberians reveals distinct genetic affinities with native Americans. Am. J. Hum. Genet. 53, 591-608.

29. Kuzeev R.G. 1991. Bashkirs and Nogays: Ethnic relationships. Tezisy Vses. konf. "Osnovnye aspekty istorikogeograficheskogo razvitiya Nogaiskoi ordy” (Abstr. AllUnion Conf. "Main aspects of historical-geographic development of the Nogay Horde"), Moscow: TerekliMekteb. pp. 45-46.

30. Tolk H.V., Pericic M., Barac L., et al. 2000. MtDNA Haplogroups in the populations of Croatian Adriatic Islands. Coll. Anthropol. 24, 267-279. 